\title{
Effect of Deformation on the Transformation Temperatures of Martensite and Bainite Structures in $\mathrm{Cu}-9.97 \% \mathrm{Al}-4.62 \% \mathrm{Mn}$ Alloy
}

\author{
E. Aldirmaz* \\ Department of Physics, Faculty of Science and Arts, Amasya University, 05100 Amasya, Turkey
}

(Received June 26, 2014; in final form June 10, 2015)

At present study of $\mathrm{Cu}-9.97 \% \mathrm{Al}-4.62 \% \mathrm{Mn}$ alloy system is used. Some physical properties of martensitic and bainite phase transformatios in $\mathrm{Cu}-9.97 \% \mathrm{Al}-4.62 \% \mathrm{Mn}$ (wt\%) alloy were investigated by means of scanning electron microscopy and differential scanning calorimetry. In scanning electron microscope observations of $\mathrm{Cu}-9.97 \% \mathrm{Al}-$ $4.62 \% \mathrm{Mn}$ alloy were noted two kinds of martensitic phases. These phases were defined as $\beta_{1}^{\prime}(\mathrm{M} 18 \mathrm{R})$ and $\gamma_{1}^{\prime}$ $(2 \mathrm{H})$ martensites structures. According to differential scanning calorimetry measurement results, the deformation induced temperature is expected to be higher than the thermally induced temperature in $\mathrm{Cu}-9.97 \% \mathrm{Al}-4.62 \% \mathrm{Mn}$ alloy for martensite and bainite structures.

DOI: 10.12693 /APhysPolA.129.40

PACS: 61.66.Dk, 68.37.Hk, 81.30.Kf, 81.30.Mh, 62.20.-x, 65.40.-b

\section{Introduction}

$\mathrm{Cu}$-based shape memory alloys are economical materials, therefore they can be used in many automotive, aerospace, robotic and biomedical fields [1]. Particularly, high temperature shape memory alloys have been studied for actuators in various aero-engine applications [2].

When the $\mathrm{Cu}$-based shape memory alloys go through ageing on $\beta$ parent phase, a series of transformations can take place, such as martensite, bainitic and eutectoid transformation. The Cu-based shape memory alloys have found that during the quenching procedure the chemical ordering sequence $\mathrm{A} 2 \rightarrow \mathrm{B} 2 \rightarrow \mathrm{DO}_{3}-\mathrm{L} 2_{1}$ [3]. In copper-based shape memory alloys, composition and heat treatment plays an important role in determining their transformation temperatures and other characteristics. The previous study is showed that the transformation temperature decreases with an increase in the aluminum and manganese contents. Also, precipitates and dislocations effects the transformation temperatures [4]. The purpose of this work is to investigate the effects of heat treatments and deformation.

\section{Experimental}

The $\mathrm{Cu}-9.97 \% \mathrm{Al}-4.62 \% \mathrm{Mn}$ (wt\%) alloy was chosen for the present study, which was prepared by vacuum induction melting under an argon atmosphere from pure (99.9\%) alloying elements. First group of samples were homogenized at $800^{\circ} \mathrm{C}$ for $1 \mathrm{~h}$ and then quenched into ice water, the second group of samples were homogenized at $800^{\circ} \mathrm{C}$ for $1 \mathrm{~h}$ and furnace cooled to $25^{\circ} \mathrm{C}$ at a rate of

*e-mail: ealdirmaz@gmail.com aproximately $2{ }^{\circ} \mathrm{C} / \mathrm{min}$ and then air cooled. These samples are denoted as A1 and A2, respectively. For scanning electron microscope observations, the samples were mechanically polished and etched into a solution composed of $2.5 \mathrm{~g} \mathrm{FeCl}_{3} \cdot 6 \mathrm{H}_{2} \mathrm{O}$ and $48 \mathrm{ml}$ methanol in $10 \mathrm{ml}$ $\mathrm{HCl}$ for $10 \mathrm{~min}$. Scanning electron microscope observations were made using a JEOL 5600 scanning electron microscope, operated at $20 \mathrm{kV}$. Subsequently, homogenized samples were plastically deformed by $7 \%$ with an INSTRON 8510-type machine, operated at a constant strain rate of $0.2 \mathrm{~mm} / \mathrm{min}$ at room temperature. These samples are designated as A3 and A4, respectively. The samples of alloy were prepared, and DSC curves were obtained. A Perkin-Elmer Sapphire model DSC equipment was used for all measurements. The transformation temperatures were determined using a differential scanning calorimetry (DSC) measurements from room temperature to $600^{\circ} \mathrm{C}$ by heating/cooling the samples at the rate of $10^{\circ} \mathrm{C} / \mathrm{min}$.

\section{Results and discussion}

In our previous studies, the crystal structures and microstructures determined for samples A1, A2, A3 and A4 $[5,6]$. As can be seen from Fig. 1, the samples consists of microstructures at room temperature. In samples A1 and A3 formed $\beta_{1}^{\prime}$ and $\gamma_{1}^{\prime}$ of martensite structures from $\mathrm{DO}_{3}$ parent phase. The bainite and $\gamma_{1}^{\prime}$ martensite variants formed by effects of thermally and deformation in sample A4 [6]. The transformation temperatures for phase transformations of $\mathrm{Cu}-9.97 \% \mathrm{Al}-4.62 \% \mathrm{Mn}$ alloy have also been determined by differential scanning calorimetry. To compare the transformation characteristics of this alloy, samples were prepared as the undeformed and deformed.

Figure 2a,b shows the differential scanning calorimetry heating and cooling curves of samples A1 and A3. Three 


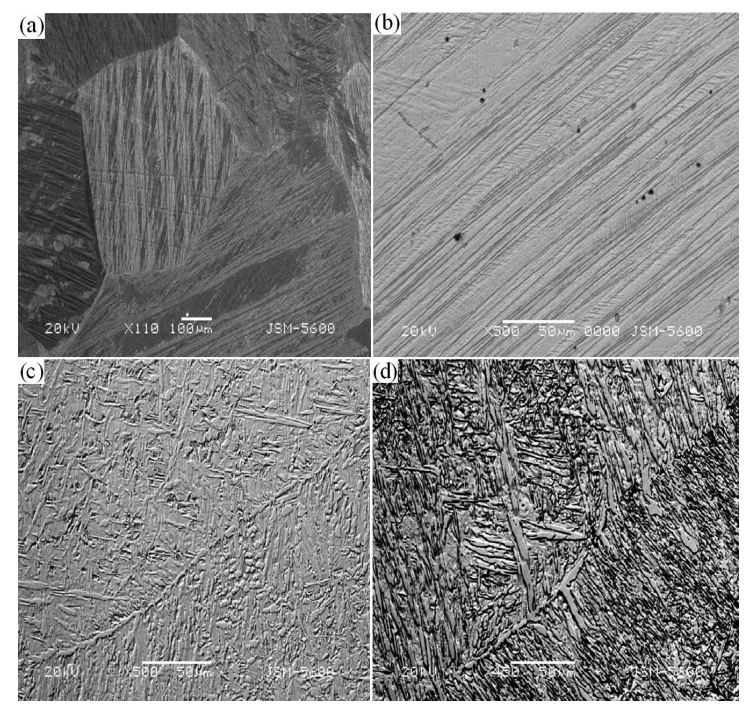

Fig. 1. SEM micrographs showing the microstructures of the $\mathrm{Cu}-\mathrm{Al}-\mathrm{Mn}$ alloy, (a) the martensitic plates with different orientations (sample A1) (b) the coarse variants of $\gamma_{1}^{\prime}$ martensites (sample A3) (c) the needle-like and plate-like bainite precipitates (sample A2) (d) the needle-like and plate-like bainite precipitates after $7 \%$ deformation (sample A4).
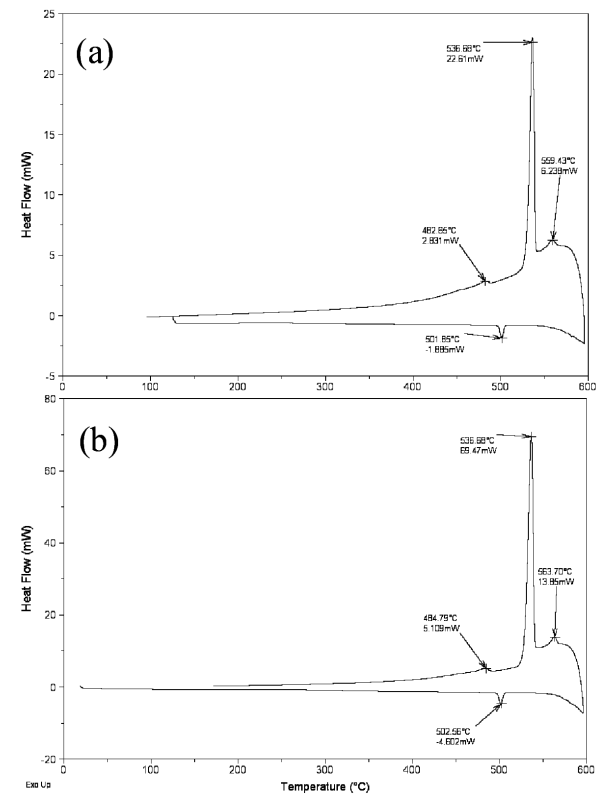

Fig. 2. Differential scanning calorimetry curves for the cooling rates of $10{ }^{\circ} \mathrm{C} / \mathrm{min}$ of samples (a) A1 and (b) A3.

transformations were observed; one during heating and three during cooling. These peaks correspond to reverse $\beta_{1} \rightarrow \beta_{1}^{\prime}+\gamma_{1}^{\prime}$ transformation and $\left(\beta \rightarrow \alpha+\gamma_{2}\right)$ eutectoid decomposition [7-10]. The $\beta$ ordered austenite undergoes an eutectoid decomposition where equilibrium state, at slow cooling, in copper-based alloys [11]. The disordered austenite $\beta$ phase is stable above $565^{\circ} \mathrm{C}$ in the binary $\mathrm{Cu}-\mathrm{Al}$ alloy system. But below this temperature, the equilibrium phases are face-centered cubic $\alpha$ phase and $\mathrm{Cu}_{9} \mathrm{Al}_{4-} \gamma_{2}$ phase [12]. According to differential scanning calorimetry measurement results, sample A3 temperature is expected to be higher than the sample A1 temperature for $\mathrm{Cu}-9.97 \% \mathrm{Al}-4.62 \% \mathrm{Mn}$ alloy. These results are shown in Fig. 2b, which indicates that the transformation temperatures are raised by an increase in stress. In our study, the driving force occurred in sample A3 during the deformation is larger than that of sample A1. On the other hand, both kind of the produced martensite structures show different transformation characteristics. Their hysteresis temperatures differ by approximately $20^{\circ} \mathrm{C}[9,10]$. The changes on the transformation temperatures are attributed to the relative stability of the product phase and closely related to the corresponding thermodynamic properties such as enthalpy. These results are in agreement with the observation made by previous works $[13,14]$.
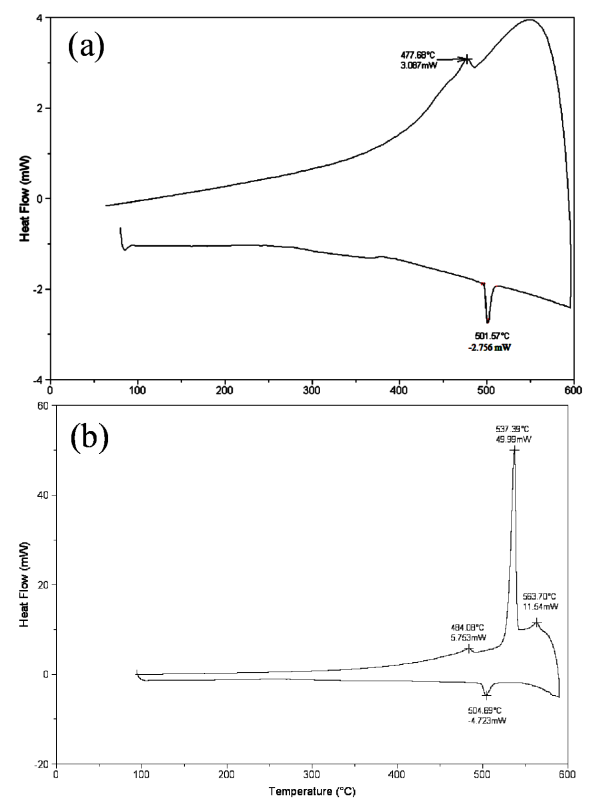

Fig. 3. Differential scanning calorimetry curves of samples for both forward and reverse transformations samples (a) A2 and (b) A4.

Differential scanning calorimetry curves of the alloy samples for both forward and reverse transformations are presented in Fig. 3a,b differential scanning calorimetry curves exhibit a prominent multi-peak behavior for the samples. During the cooling from $600^{\circ} \mathrm{C}$ to room temperature, the bainitic transformation starts $\left(B_{\mathrm{s}}\right)$ at $481^{\circ} \mathrm{C}$ for sample A2 and at $486^{\circ} \mathrm{C}$ for sample A4. The bainitic transformation finishes $\left(B_{\mathrm{f}}\right)$ at a temperature of $466^{\circ} \mathrm{C}$ and $470^{\circ} \mathrm{C}$ for samples $\mathrm{A} 2$ and $\mathrm{A} 4$, respectively. During heating of the samples, the reverse transformation starts at a temperature of $497^{\circ} \mathrm{C}\left(\mathrm{A}_{\mathrm{s}}\right)$ and finishes at $513^{\circ} \mathrm{C}\left(\mathrm{A}_{\mathrm{f}}\right)$ for sample A2. It was determined that reverse transformations starts at $500^{\circ} \mathrm{C}$ and finishes at $518^{\circ} \mathrm{C}$ for sample $\mathrm{A} 4$. In addition, the sample $\mathrm{A} 4$ observed a sharp peak after the deformation. This sharp peak corresponds to $536^{\circ} \mathrm{C}\left(\beta \rightarrow \alpha+\gamma_{2}\right)$ eutectoid decomposition $[8,9]$. 
It is believed that both the nucleation and growth mechanisms of bainite are shear, which are governed by solute atom diffusion. It was found that the activation energy for bainite nucleation is proportional to the driving force available for transformation $[15,16]$. According to differential scanning calorimetry measurement results, sample A2 temperature is expected to be higher than the sample A4 temperature for $\mathrm{Cu}-9.97 \% \mathrm{Al}-4.62 \% \mathrm{Mn}$ alloy. This behavior can be explained by taking account of crystal defects brought about by plastic deformation such as dislocations [17]. These defects are increased in transformation temperatures [18].

\section{Conclusion}

The copper-based alloy are important for technological applications and the transformation temperatures vary with the variation applied by various thermal treatments and deformation. The transformation temperatures values of samples are increased with applied deformation. In this study, it has been observed that the transformation temperatures are high for the alloy studied. Therefore, $\mathrm{Cu}-9.97 \% \mathrm{Al}-4.62 \% \mathrm{Mn}$ alloy can be suitably designed for use in different fields where high temperature applications such as in actuators and automotive components. Our study give rise to new application opportunities and this is particularly true in the development of new materials.

\section{References}

[1] J. Chen, Z. Li, Y.Y. Zhao, J. Alloys Comp. 480, 481 (2009).

[2] J. Ma, I. Karaman, R.D. Noebe, Int. Mater. Rev. 55, 257 (2010).
[3] J. Soltys, Phys. Status Solidi A 63, 401 (1981).

[4] U.S. Mallik, V. Sampath, Mater. Sci. Eng. A 478, 48 (2008).

[5] E. Aldırmaz, I. Aksoy, Arab. J. Sci. Eng. 39, 575 (2014).

[6] E. Aldırmaz, I. Aksoy, J. Min. Metall. Sect. BMetall. 50, 87 (2014).

[7] M.L. Castro, R. Romero, Mater. Sci. Eng.-A Struct. 287, 66 (2000).

[8] Z.Y. Pan, Z. Li, M.P. Wang, C.P. Deng, S.H. Li, F. Zheng, Mater. Sci. Eng. 467, 104 (2007).

[9] V. Recarte, R.B. Perez-Saez, E.H. Bocanegra, M.L. Nó, J. San Juan, Metall. Mater. Trans. A 33, 2581 (2002).

[10] J. Malimanek, N. Zarubova, Scr. Metall. Mater. 32, 1347 (1995).

[11] P. Villars, A. Prince, H. Okamoto, Handbook of Ternary Alloy Phase Diagrams, Vol. 3, ASM International. 1995, p. 3297.

[12] S.M. Chentouf, M. Bouabdallah, H. Cheniti, A. Eberhardt, E. Patoor, A. Sari, Mater. Charact. 61, 1187 (2010).

[13] U.S. Mallik, V. Sampath, J. Alloys Comp. 459, 142 (2008).

[14] J.L. Pelegrina, R. Romero, Mater. Sci. Eng. A 282, 16 (2000).

[15] H.K.D.H. Bhadeshia, D.V. Edmonds, Acta Metall. 28, 1265 (1980).

[16] L.C. Chang, H.K.D.H. Bhadeshia, Mater. Sci. Technol. 11, 874 (1995).

[17] M.K. Kang, M.X. Zhang, M. Zhu, Acta Mater. 54, 2121 (2006).

[18] D.A. Porter, K.E. Easterling, Phase Transformations in Metals and Alloys, Vol. 5, Pergamon Press, London 1989, p. 303. 